\title{
Przymusowa licencja eksportowa JAKO PUBLICZNOPRAWNY INSTRUMENT ZWALCZANIA I ZAPOBIEGANIA CHOROBOM ZAKAŹNYM
}

Choroby zakaźne to duże wyzwanie dla współczesnej medycyny. Zgodnie z charakterystykami wskazanymi w naukach medycznych choroby te mogą być powodowane specyficznym czynnikiem zakaźnym lub jego toksycznym produktem, powstają poprzez przeniesienie tego czynnika lub jego produktu w sposób bezpośredni lub pośredni z osoby zakażonej lub zwierzęcia na podatnego gospodarza ${ }^{1}$. Często towarzyszy im złamanie sił odpornościowych organizmu, co powoduje duży dylemat zwłaszcza w zwalczaniu ich skutków. Pozostają one jednym z ważniejszych problemów zdrowotnych we wszystkich krajach, zarówno rozwiniętych, jak i tam, gdzie rozwój został zahamowany². Skala i zasięg problemów zdrowotnych powstających dla całych społeczeństw, jakie wiążą się z występowaniem chorób zakaźnych, a także ich transgraniczny charakter

* Dr nauk prawn., Katolicki Uniwersytet Lubelski Jana Pawła II, Katedra Prawa Administracyjnego; katarzyna.melgies@gmail.com.

1 R. Beaglehole, R. Bonita, T. Kjellström, Podstawy epidemiologii, Szkoła Zdrowia Publicznego Instytutu Medycyny Pracy im. prof. J. Nofera, Łódź 2002, s. 124.

2 Bez wątpienia nabyty zespół braku odporności (AIDS) czy tzw. ptasia grypa to jedne $z$ najbardziej tragicznych i znanych chorób zakaźnych, przy czym efekty w zakresie radzenia sobie z zapobieganiem im i zwalczaniem ich skutków znacząco się różnią. Zaawansowane prace rozwojowe nie są $\mathrm{w}$ stanie nadążyć i efektywnie zapobiec tragicznym skutkom tych chorób. Dla przykładu masowa ekspansja terapii antyretrowirusowej (ART) zmniejszyła liczbę osób umierających z powodu HIV do około 1,1 mln w 2015 r., co stanowi o 45\% mniej niż w 2005 r., kiedy śmiertelność związana z HIV osiągnęła najwyższy poziom - dane pochodzą z PREVENT HIV, TEST AND TREAT AIL, WHO SUPPORT FOR COUNTRY IMPACT, Progress Report 2016, Szwajcaria 2016, http://www.who.int/hiv/pub/ progressreports/2016-progress-report/en/ [dostęp: 21.08.2017 r.]. 
determinują działania lokalnych władz publicznych oraz organizacji międzynarodowych realizujących swoje zadania w obszarach związanych z ochroną zdrowia.

Łatwy sposób rozprzestrzeniania się chorób zakaźnych powoduje dotkliwe skutki zwłaszcza w dobie postępującej globalizacji ${ }^{3}$. Częste masowe przesiedlanie się grup powodowane czynnikami ekonomicznymi, religijnymi, jak również konfliktami zbrojnymi uzasadnia napływ ludności w części świata początkowo wolne od nich ${ }^{4}$. Migracje są zjawiskiem nieuniknionym, które, jak się wydaje, stanowi element charakteryzujący współczesne zjawiska społeczne w ich wymiarze ponadpaństwowym. Niewątpliwie opisane okoliczności sprzyjają wydłużaniu się łańcucha nosicieli chorób zakaźnych, a tym samym rozprzestrzenianiu się chorób. Rola poszczególnych państw działających autonomicznie w zakresie ochrony zdrowia w obszarze zwalczania chorób zakaźnych wydaje się być niewystarczająca głównie ze względu na transgraniczną specyfikę omawianego zjawiska. Stanowi to powód przesądzający o potrzebie podejmowania działań wspólnych, w tym ponadpaństwowych, pozwalających zachować swoistą synergię, tak aby móc osiągnąć oczekiwane rezultaty $\mathrm{w}$ postaci efektywnego prowadzenia procesu profilaktycznego i terapeutycznego w stosunku do osób dotkniętych przez choroby zakaźne.

Należy również podkreślić inną istotną okoliczność. Specyfika i przebieg tych chorób stanowi wciąż poważne wyzwanie dla medycyny w obszarze związanym $\mathrm{z}$ badaniami i rozwojem $\mathrm{w}$ znalezieniu takich rozwiązań chemicznych czy biologicznych, w tym leków i szczepionek, które będą skutecznie zapobiegać i niweczyć skutki tych chorób. Sygnalizowana trudność wiąże się zwłaszcza z tym, że skuteczność wynalezionych rozwiązań, nawet jeżeli już zostanie osiągnięta, często nie jest trwała, gdyż organizmy nosicieli czy osób zarażonych uodparniają się. Nakłady czynione na badania, które mają doprowadzić do znalezienia formuł dających pozytywne efekty w zapobieganiu i leczeniu chorób zakaźnych, często skłaniają podmioty badawcze czy firmy farmaceutyczne, korzystające z rezultatów tych badań w sposób komercyjny, do sięgania po ochronę patentową 5 .

${ }^{3}$ Fakt, że coraz więcej i częściej podróżujemy po świecie, czy to służbowo, czy prywatnie, nie wydaje się budzić wątpliwości.

${ }^{4}$ Wskazać tu także należy przyczynienie się samych państw poprzez ich zaangażowanie $\mathrm{w}$ prace nad bronią biologiczną.

${ }^{5}$ Możliwość uzyskania ochrony patentowej gwarantowana jest przez szeregu aktów prawnych o charakterze międzynarodowym, unijnym oraz krajowym. W wymiarze mię- 
Wyłączność prawna wynikająca z tej ochrony daje sposobność do odzyskania w ustawowo określonym czasie i warunkach ${ }^{6}$ własnych nakładów finansowych związanych $\mathrm{z}$ odroczoną $\mathrm{w}$ czasie kontrybucją do domeny publicznej produktów związanych z ochroną zdrowia, w szczególności leków, w tym szczepionek ${ }^{7}$. Z drugiej zaś strony możliwość decydowania przez właściciela patentu zarówno o tym, czy chronione rozwiązanie w ogóle zostanie $\mathrm{w}$ praktyce wykorzystane, a także o tym, w jakiej cenie i na jakich warunkach produkty wytworzone według wynalazku będą dostępne, powoduje uzyskanie uprzywilejowanej pozycji na rynku, dającej znaczącą przewagę negocjacyjną. Oczywiście sytuacja prawna właścicieli patentów jest usprawiedliwiona okolicznościami uzasadniającymi ich uzyskanie, nie zasługuje jednak na ochronę w sytuacji, gdy jest nadużywana lub gdy wartości wyższe przemawiają za tym, by chronić je niezależnie od woli właściciela patentu. Należy mieć na uwadze to, że zdrowie i życie człowieka jako wartości pozycjonowane hierarchicznie najwyżej $\mathrm{w}$ aksjologii dóbr prawnie chronionych w społecznościach, także międzynarodowych, mogą uzasadniać ingerencję władz publicznych w sferę uprawnień pierwotnie zastrzeżonych dla podmiotów prywatnych - właścicieli praw. Władze te reprezentują zarówno organizacje międzynarodowe, jak i poszczególne państwa. Podmioty te widząc potrzebę synergii działań profilaktycznych oraz terapeutycznych w odniesieniu do chorób zakaźnych, od wielu lat nie ustają w wysiłkach mających na celu znalezienie rozwiązań prawnych pozwalających na osiągniecie pozytywnych rezultatów w tych dziedzinach. Wskazuje się w szczególności na pewne

dzynarodowym istotne znaczenie ma w szczególności Porozumienie w sprawie handlowych aspektów praw własności intelektualnej - Agreement on Trade Related Aspects of Intellectual Property Rights (TRIPS) - stanowiące załącznik 1c) do Konwencji o ustanowieniu Światowej Organizacji Handlu, Dz.U. z 1996 r. Nr 32, poz. 143, dalej: Porozumienie TRIPS. W Polsce aktem właściwym w zakresie udzielania patentów jest ustawa z dnia 30 czerwca 2000 r. - Prawo własności przemysłowej, tekst jedn., Dz.U. z 2017 r. poz. 776, dalej: p.w.p.

${ }^{6}$ Por. art. 27 i n. Porozumienia TRIPS.

7 Szerzej na temat zakresu i postępów w pracach badawczo-rozwojowych prowadzonych w odniesieniu do poszczególnych chorób zakaźnych oraz strategii patentowych stosowanych w celu uzyskiwania ochrony dla szczepionek na wybrane choroby zakaźne, jak również krajów, które przodują w pierwszych zgłoszeniach patentowych, w: Patent Landscape Report on Vaccines for Selected Infectionues Diseases, przygotowany dla Światowej Organizacji Własności Intelektualnej przez France Innovation Scientifique \& Transfert FIST S.A., 2012, http://www.wipo.int/edocs/pubdocs/en/patents/946/wipo_pub_946_3.pdf [dostęp: 21.08.2017 r.]. Patrz także: J. Tudor, Compulsory licensing in the European Union, „Journal of International Commercial Law” 2012, nr 2, s. 222 i n. 
obszary świata, gdzie choroby zakaźne szczególnie intensywnie się rozprzestrzeniaja, a kraje te ze względu na swój potencjał ekonomiczny nie są w stanie zaspokoić oczekiwań finansowych właścicieli patentów chroniących leki, które mogą być skuteczne w walce $\mathrm{z}$ chorobami zakaźnymi, jak również udźwignąć całej infrastruktury związanej z uruchomieniem produkcji tych preparatów i ich dystrybucji.

Jednym z instrumentów, które mają wspomóc kraje słabiej rozwinięte i pozwolić wbrew woli właściciela patentu wejść w obszar jego chronionych uprawnień, umożliwiając korzystanie z wynalazku innemu podmiotowi ze względu na potrzebę ochrony zdrowia, w tym zwalczania chorób zakaźnych jest - umownie nazwana dla celów niniejszej publikacji - tzw. przymusowa licencja eksportowa. Instytucja ta została uregulowana w rozporządzeniu 816/2006 Parlamentu Europejskiego i Rady z dnia 17 maja 2006 r. w sprawie udzielania licencji przymusowych na patenty dotyczące wytwarzania produktów farmaceutycznych przeznaczonych na wywóz do krajów, w których występują problemy związane ze zdrowiem publicznym ${ }^{8}$. Instrument ten w zamierzeniu jego twórców ma stanowić element szerszych działań podejmowanych w skali europejskiej i międzynarodowej w celu rozwiązania problemów dotyczących zdrowia publicznego, w tym tych, które związane są z profilaktyką i zwalczaniem chorób zakaźnych. Poniższe rozważania mają na celu przybliżenie tej instytucji i weryfikację jej skuteczności jako narzędzia przeciwdziałania przyczynom i skutkom chorób zakaźnych.

Pojęcie licencji przymusowej ${ }^{9} \mathrm{w}$ doktrynie prawa ujmowane jest w sposób, który wskazuje, że źródłem zezwolenia udzielonego wbrew woli podmiotu uprawnionego z patentu na eksploatację chronionego dobra jest decyzja organu administracji, wydana jako konstytutywne rozstrzygnięcie administracyjne ${ }^{10}$. Przesądza o tym jednostronny i władczy charakter indywidulanego aktu administracyjnego. Jest ona uznawana za jeden z kluczowych instrumentów zabezpieczania interesu publicznego

${ }^{8}$ Dz.Urz. UE L 157 z 9 czerwca 2006 r., s. 1, dalej: rozporządzenie 816/2006. Zob. K. Dobieżyński, Licencja przymusowa w ustawie z 2000 r. Prawo własności przemysłowej (Charakterystyka ogólna), „Rzecznik Patentowy” 2010, nr 1, s. 44 i n.

${ }_{9}$ Do instytucji tej odwołuje się m.in. art. 82 p.w.p.

${ }^{10}$ Tak w szczególności M.K. Kolasiński, Ograniczenia własności intelektualnej w analizie konstrukcyjnej, Zeszyty Naukowe Uniwersytetu Jagiellońskiego 2008, nr 1, s. 151 i n. 
$\mathrm{w}$ uregulowaniach dotyczących prawa patentowego ${ }^{11}$. Jako akt administracyjny służy ochronie wartości determinujących ten interes.

Porozumienie TRIPS ${ }^{12}$, wyznaczając $\mathrm{w}$ tym zakresie minimalne standardy, w art. 31 wprowadziło regulacje dotyczące zasad użycia rozwiązania chronionego patentem bez upoważnienia posiadacza praw ${ }^{13}-\mathrm{w}$ sytuacji gdy ustawodawstwo wewnętrzne zezwala na takie użycie, łącznie z możliwością wykorzystania tego rozwiązania przez rząd lub strony trzecie upoważnione przez rząd ${ }^{14}$. Standardy te okazały się być zbyt rygorystyczne i nie do końca dostosowane do możliwości zarówno finansowych, jak i organizacyjnych państw słabiej rozwiniętych. W konsekwencji dnia 14 listopada 2001 r. Czwarta Konferencja Ministerialna Światowej Organizacji Handlu (WTO) przyjęła deklarację z Doha dotyczącą porozumienia w sprawie handlowych aspektów praw własności intelektualnej (porozumienie TRIPS) i zdrowia publicznego ${ }^{15}$. Deklaracja ta potwierdziła zasadę, że postanowienia porozumienia TRIPS mają być interpretowane i wdrażane w sposób zapewniający prawo do ochrony zdrowia publicznego i umożliwiający wszystkim dostęp do lekarstw, a w szczególności prawo każdego państwa członkowskiego WTO do ustalenia, co jest „stanem katastrofy naturalnej w kraju” czy „sytuacją skrajnie nagłą", w celu uzasadnienia przyznania licencji przymusowych. Ponadto, wziąwszy pod uwagę problemy, na jakie napotykają kraje o ograniczonej lub nieistniejącej zdolności produkcyjnej w sektorze farmaceutycznym, deklaracja zaleciła Radzie Ogólnej znalezienie szybkiego rozwiązania tej kwestii. Deklaracja uznaje, że każdy członek WTO ma prawo udzielania licencji

11 A. Michalak, Interes publiczny i jego oddziatywanie na powstanie, treść i wykonywanie prawa własności intelektualnej, Warszawa 2012, s. 162.

12 Por. M. Barczewski, Prawa własności intelektualnej w Światowej Organizacji Handlu a dostęp do produktów leczniczych, Warszawa 2013, s. 96 i n.

${ }^{13}$ Art. 31 TRIPS ma w szczególności na względzie instytucję licencji przymusowej, aczkolwiek sam dokument nie posługuje się tym określeniem.

${ }^{14}$ Szerzej na temat historii wprowadzenia analizowanych regulacji patrz: J.H. Reichman, Compulsory licensing of patented pharmaceutical inventions: evaluating the options, Law Med Ethics 2009, Summer, 37(2), s. 1-5, https:/www.ncbi.nlm.nih.gov/pmc/articles/ PMC2893582/ [dostęp: 21.08.2017 r.], a także M.K. Kolasiński, Ochrona własności intelektualnej w odniesieniu do farmaceutyków w państwach Trzeciego Świata, PiP 2007, nr 8, s. 83 i n.; A. Miszczak, Licencjonowanie przymusowe w prawie unijnym oraz umowach międzynarodowych wiążących Rzeczpospolita Polska, RPEiS 2016, nr 4, s. 126; M.A. Desai, Compulsory licensing: Procedural requirements under the TRIPS agreement, "Pharmaceuticals Policy and Law” 2016, vol. 18 , s. 31-44.

15 Treść deklaracji z Doha dostępna jest pod adresem: https://www.wto.org/english/ thewto_e/minist_e/min01_e/mindecl_trips_e.htm [dostęp: 21.08 .2017 r.]. 
przymusowych i swobodę określenia podstaw, na jakich ich udziela. Deklaracja potwierdza również, że członkowie WTO, którzy nie posiadają wystarczających lub żadnych zdolności produkcyjnych w sektorze farmaceutycznym, mogą napotykać na trudności w skutecznym wykorzystaniu licencji przymusowych (ust. 6 deklaracji) ${ }^{16}$. W dniu 30 sierpnia 2003 r. Rada Ogólna WTO, w związku z oświadczeniem wygłoszonym przez jej przewodniczącego, przyjęła decyzję w sprawie wykonania ust. 6 deklaracji z Doha w sprawie Porozumienia TRIPS i Zdrowia Publicznego ${ }^{17}$. Co do zasady, decyzja odstępuje od niektórych zobowiązań dotyczących udzielania licencji przymusowych określonych w Porozumieniu TRIPS w celu uwzględnienia potrzeb członków WTO o niewystarczających zdolnościach produkcyjnych ${ }^{18}$. Swoim zakresem regulacja obejmuje wszelkie produkty (substancje czynne czy zestawy diagnostyczne), które są objęte ochroną patentową lub których wytwarzanie jest nią objęte i które można wykorzystać w celu rozwiązania problemów ochrony zdrowia w rozwijających się krajach, zwłaszcza tych problemów, które wynikają z HIV/AIDS, gruźlicy (tuberculosis, TB), malarii i innych chorób zakaźnych. Wskazana lista chorób wynika z ustępu 1 deklaracji i nie ma charakteru zamkniętego ${ }^{19}$. W decyzji stwierdza się, że będzie ona wykorzystywana $\mathrm{w}$ dobrej wierze $\mathrm{w}$ celu rozwiązywania problemów dotyczących zdrowia publicznego, a nie dla celów polityki przemysłowej lub handlowej. Decyzja uznaje za istotne takie kwestie, jak np. ochrona leków

16 Szerzej patrz: F.M. Abbott, R.V. Van Puymbroeck, Compulsory Licensing for Public Health A Guide and Model Documents for Implementation of the Doha Declaration Paragraph 6 Decision, The World Bank Washington, 2005, http://documents.worldbank.org/curated/ en/173701468337882214/pdf/334260rev0pub.pdf [dostęp: 21.08.2017 r.]; R. Kampf, Special Compulsory Licences For Export of Medicines: Key Features of WTO Members' Implementing Legislation, Staff Working Paper ERSD-2015-07 31 July 2015; World Trade Organization Economic Research and Statistics Division; https://www.wto.org/english/res_e/reser_e/ ersd201507_e.pdf [dostęp: 21.08.2017 r.].

17 Por. V.B. Kerry, K. Lee, TRIPS, the Doha declaration and paragraph 6 decision: what are the remaining steps for protecting access to medicines?, Global Health 2007, May 24, https:// www.ncbi.nlm.nih.gov/pmc/articles/PMC1892549/ [dostęp: 21.08.2017 r.].

${ }^{18}$ Lista krajów, które implementowały do swoich systemów prawnych stosowne regulacje $\mathrm{w}$ zakresie przyjęcia rozwiązań wynikających z deklaracji z Doha, aktualna na dzień 6 stycznia 2016 r., znajduje się pod adresem: https://www.wto.org/english/tratop_e/ trips_e/par6laws_e.htm [dostęp: 21.08.2017 r.].

19 Por. Promoting Access to Medical Technologies and Innovation. Intersections between public health, intellectual property and trade, World Health Organization, World Intellectual Property Organization and World Trade Organization 2013, s. 222, https://www.wto.org/ english/res_e/booksp_e/pamtiwhowipowtoweb13_e.pdf [dostęp: 21.08.2017 r.]. 
przed dostaniem się w niepowołane ręce. W celu zapewnienia, że system będzie służył najbardziej potrzebującym, kraje rozwinięte będące członkami WTO (między innymi wszystkie państwa członkowskie UE) podjęły zobowiązanie, że nie będą korzystać z systemu jako importerzy. Kraje rozwijające się o wysokim dochodzie oświadczyły, że będą korzystać z systemu tylko w wyjątkowych okolicznościach. Wszyscy członkowie WTO mają prawo do działania w charakterze eksporterów ${ }^{20}$.

W konsekwencji Parlament Europejski przyjął rozporządzenie nr 816/2006. Zgodnie z pkt 3 preambuły do rozporządzenia 816/2006 ma ono stanowić część szerszych działań podejmowanych w skali europejskiej i międzynarodowej w celu rozwiązania problemów dotyczących zdrowia publicznego, doświadczanych przez kraje najsłabiej rozwinięte i inne kraje rozwijające się. Chodzi tu w szczególności o poprawę dostępności do bezpiecznych do bezpiecznych i skutecznych leków, w tym leków w skojarzeniach ustalonych dawek, po przystępnych cenach i przy zagwarantowanej jakości. W związku z tym, że rozporządzenie 816/2006 stanowi element szerszych działań mających na celu zapewnienie krajom rozwijającym się dostępu do leków po przystępnych cenach, ustanowiono działania uzupełniające w programie działania Komisji Europejskiej: przyspieszenie działań na rzecz zwalczania HIV/AIDS, malarii i gruźlicy w kontekście ograniczania ubóstwa ${ }^{21}$ oraz w komunikacie Komisji w sprawie spójnych ram polityki europejskiej dotyczących działań zewnętrznych w celu zwalczania HIV/AIDS, malarii i gruźlicy ${ }^{22}$.

Przyjęcie rozporządzenia 816/2006 potwierdziło potrzebę zapewnienia we wszystkich krajach członkowskich UE takich samych warunków udzielania licencji przymusowych na wytwarzanie i sprzedaż produktów

${ }^{20}$ Por. R. Kampf, Special Compulsory..., s. 6.

${ }^{21}$ Zob. Decyzja nr 1209/2003/WE Parlamentu Europejskiego i Rady z dnia 16 czerwca 2003 r. w sprawie udziału Wspólnoty w podjętym przez kilka Państw Członkowskich programie badawczo-rozwojowym mającym na celu rozwijanie nowych interwencji klinicznych w celu zwalczania HIV/AIDS, malarii i gruźlicy w ramach długoterminowego partnerstwa między Europą a krajami rozwijającymi się, http://eur-lex.europa.eu/legal-content/PL/TXT/PDF/?uri=CELEX:32003D1209\&from=PL.

${ }^{22}$ Zob. Komunikat Komisji dla Rady i Parlamentu Europejskiego Spójne ramy polityki europejskiej dotyczące działań zewnętrznych w celu zwalczania HIV/AIDS, malarii i gruźlicy, http://www.europarl.europa.eu/RegData/docs_autres_institutions/commission_europeenne/com/2004/0726/COM_COM(2004)0726_PL.pdf , Rezolucja Parlamentu Europejskiego z dnia 24 kwietnia 2007 r. w sprawie zwalczania HIV/AIDS w Unii Europejskiej i w państwach z nią sąsiadujących w latach 2006-2009 (2006/2232(INI)), http://eur-lex. europa.eu/legal-content/PL/TXT/PDF/?uri=CELEX:52007IP0137\&from=PL. 
farmaceutycznych przeznaczonych na wywóz. Motywowano to w szczególności zamiarem zapobieżenia zniekształceniu konkurencji między podmiotami działającymi na jednolitym rynku. Analogiczne zasady zostały przyjęte także $\mathrm{w}$ zakresie stosowania środków zapobiegających ponownemu przywozowi na terytorium UE produktów wytworzonych na mocy decyzji ${ }^{23}$. Tym samym Komisja potwierdziła, że Unia Europejska uznaje, że promowanie transferu technologii i tworzenia zdolności produkcyjnych $\mathrm{w}$ krajach, które nie posiadają zdolności produkcyjnych w sektorze farmaceutycznym, lub w których są one niedostateczne, jest w najwyższym stopniu pożądane w celu ułatwienia i zwiększenia wytwarzania produktów farmaceutycznych przez te kraje $\mathrm{e}^{24}$.

Rozporządzenie 816/2006 ustanawia procedurę udzielania licencji przymusowych w odniesieniu do patentów i dodatkowych świadectw ochronnych ${ }^{25}$ dotyczących wytwarzania i sprzedaży produktów farmaceutycznych w przypadku, gdy produkty te są przeznaczone na wywóz do kwalifikujących się do ich otrzymania krajów przywozu, potrzebujących takich produktów w celu zaradzenia problemom dotyczącym zdrowia publicznego ${ }^{26}$. Organem właściwym, zgodnie z art. 3 rozporządzenia 816/2006, w zakresie wydawania decyzji w tym przedmiocie jest organ kompetentny do udzielania licencji przymusowych na mocy krajowego prawa patentowego ${ }^{27}$. Rozporządzenie wskazuje państwa kwalifikowane jako kraje wywozu. Są to zgodnie z art. 4 rozporządzenia 816/2006: a) kraje najsłabiej rozwinięte, figurujące jako takie w wykazie Organizacji Narodów Zjednoczonych; b) każdy członek WTO, inny niż członkowie

${ }^{23}$ Por. R. Stankiewicz, Model racjonalizacji dostępu do produktu leczniczego, Warszawa 2014, s. 148.

${ }^{24}$ Por. pkt 13 preambuły do rozporządzenia 816/2006.

${ }^{25}$ Instytucja dodatkowego świadectwa ochronnego, która umożliwia przedłużenie ochrony patentowej w zakresie objętym rejestracją produktu leczniczego (dopuszczeniem do obrotu), została uregulowana w rozporządzeniu Parlamentu Europejskiego i Rady (WE) nr 469/2009 z 6.05.2009 r. dotyczącym dodatkowego świadectwa ochronnego dla produktów leczniczych. Stanowi ono ujednoliconą wersję rozporządzenia Rady (EWG) nr 1768/92 z 18.06.1992 r. dotyczącego stworzenia dodatkowego świadectwa ochronnego dla produktów leczniczych, Dz.Urz. UE, polskie wydanie specjalne, rozdz. 13, t. 11, s. 200-204.

26 Art. 1 rozporządzenia 816/2006.

${ }_{27}$ Zgodnie z art. 82 p.w.p. w Polsce jest to Urząd Patentowy RP; szerzej na temat krajowych licencji przymusowych patrz S. Sołtysiński, Licencja przymusowa, [w:] R. Skubisz (red.), System Prawa Prywatnego, t. 14a, Prawo własności przemysłowej, Warszawa 2012, s. 654 i n.; T. Targosz, Licencja przymusowa, [w:] E. Nowińska, K. Szczepanowska-Kozłowska (red.), System Prawa Handlowego, t. 3, Prawo własności przemysłowej, Warszawa 2015, s. 416417; K. Dobieżyński, Licencja przymusowa... 
zaliczający się do krajów najsłabiej rozwiniętych, który powiadomił Radę ds. TRIPS o swoim zamiarze korzystania z systemu jako importer, w tym czy będzie korzystał z systemu w całości, czy w ograniczonym zakresie; c) każdy kraj niebędący członkiem WTO, ale uwzględniony w wykazie krajów o niskich dochodach Komisji Pomocy Rozwojowej OECD, z produktem krajowym brutto per capita wynoszącym poniżej 745 USD, i który powiadomił Komisję o swoim zamiarze korzystania z systemu jako importer, w tym czy będzie korzystał z systemu w całości, czy w ograniczonym zakresie.

Jednakże każdy członek WTO, który złożył oświadczenie do WTO, że nie będzie korzystał z systemu jako importer, nie jest kwalifikującym się krajem przywozu. W odniesieniu do krajów niebędących członkami WTO, jednak spełniających warunki wskazane w art. 4 rozporządzenia 816/2006 przyjęto tryb szczególny ${ }^{28}$. Rozporządzenie określa szczegółowo warunki formalne i materialne wniosku, wskazując, że może go złożyć każda osoba w kraju członkowskim, w którym patenty lub dodatkowe świadectwa ochronne są skuteczne i obejmują zamierzone działania tej osoby w zakresie wytwarzania i sprzedaży na wywóz. Właściwy organ niezwłocznie zawiadamia o tym fakcie uprawnionego z patentu lub dodatkowego świadectwa ochronnego, umożliwiając mu jednocześnie wypowiedzenie się poprzez zgłoszenie uwag i złożenie istotnych informacji. Organ ten dokonuje sprawdzenia prawdziwości tego wniosku, w tym także $\mathrm{w}$ aspekcie merytorycznym. Warunkiem koniecznym do uzyskania licencji przymusowej jest, zgodnie z art. 9 rozporządzenia 816/2006, wykazanie przez wnioskodawcę, że dołożył on starań, aby otrzymać upoważnienie od posiadacza prawa, oraz że starania te nie przyniosły pozytywnych skutków w okresie trzydziestu dni przed złożeniem wniosku. Powyższy wymóg nie dotyczy sytuacji krytycznych w państwie lub w innych nadzwyczajnych okolicznościach wymagających podjęcia pilnych działań, jak również w wypadkach publicznego użycia dla celów niekomercyjnych zgodnie $z$ art. 31 lit. b) porozumienia TRIPS. W sytuacji gdy licencja zostanie udzielona, to zgodnie $\mathrm{z}$ art. 12 rozporządzenia 816/2006 właściwy organ w kraju członkowskim informuje o tym fakcie za pośrednictwem KE Radę ds. TRIPS o udzieleniu licencji oraz o jej szczegółowych warunkach. W sytuacji gdy którykolwiek z warunków nie został spełniony lub wniosek nie zawiera innych niezbędnych elementów - wówczas

\footnotetext{
${ }^{28}$ Art. 5 rozporządzenia 816/2006.
} 
jest odrzucany. Prawo krajowe rozstrzyga w kwestiach dotyczących zasad wniesienia odwołania ${ }^{29}$.

Udzielona $\mathrm{w}$ formie indywidulanego aktu administracyjnego przymusowa licencja eksportowa stanowi zezwolenie udzielone wbrew woli podmiotu uprawnionego z patentu do korzystania z wynalazku chronionego tym patentem. Zezwolenie to jest nieprzenoszalne, $\mathrm{z}$ zastrzeżeniem możliwości przeniesienia go z tą częścią przedsiębiorstwa lub wartości przedsiębiorstwa, która korzysta z licencji. Udzielona licencja ma charakter niewyłączny. Decyzja administracyjna określa szczególne warunki, jakie mają być spełnione przez licencjobiorcę. W szczególności określa ilość produktu lub produktów wytworzonych na podstawie licencji, zastrzegając, że nie może przekraczać ona ilości niezbędnej do zaspokojenia potrzeb kraju lub krajów przywozu wymienionych we wniosku, z uwzględnieniem ilości produktu lub produktów wytworzonych zgodnie $\mathrm{z}$ innymi licencjami przymusowymi udzielonymi gdziekolwiek indziej, a także okres ważności licencji. Licencja jest ściśle ograniczona do wszystkich działań niezbędnych w celu wytworzenia danego produktu na wywóz i jego dystrybucji w kraju lub krajach wymienionych we wniosku. Żadnego produktu wytworzonego lub sprowadzonego na podstawie licencji przymusowej nie wolno oferować do sprzedaży lub wprowadzać do obrotu $\mathrm{w}$ żadnym innym kraju poza krajami wymienionymi we wniosku, z wyjątkami wskazanymi w rozporządzeniu. Ponadto produkty wytworzone na podstawie licencji są zidentyfikowane w wyraźny sposób, za pomocą specjalnych etykiet lub oznakowań, jako wytworzone zgodnie z rozporządzeniem 816/2006. Odróżnia się je od tych, które zostały wytworzone przez posiadacza praw, za pomocą specjalnego opakowania lub poprzez nadanie produktowi specjalnej barwy lub kształtu, pod warunkiem że takie odróżnienie jest wykonalne i nie ma istotnego wpływu na cenę. Opakowanie oraz dokumentacja uzupełniająca wskazuja, że produkt jest przedmiotem licencji przymusowej na mocy rozporządzenia 816/2006 poprzez podanie nazwy właściwego organu oraz numer identyfikacyjnego, jeśli jest stosowany, oraz wyraźnie zaznaczając, że produkt jest przeznaczony wyłącznie na wywóz i dystrybucję w danym kraju lub krajach przywozu. Szczegółowe informacje na temat właściwości produktu są udostępniane organom celnym państw członkowskich.

${ }^{29}$ Postępowanie prowadzone przez Urząd Patentowy RP przebiega zgodnie z procedurą uregulowaną w ustawie z dnia 14 czerwca 1960 r. - Kodeks postępowania administracyjnego, tekst jedn., Dz.U. z 2017 r. poz. 1257. 
Przed wysyłką produktu do kraju lub krajów wymienionych we wniosku licencjobiorca zamieszcza na stronie internetowej następujące informacje: ilości dostarczane na podstawie licencji oraz kraje przywozu, do których są one dostarczane; cechy odróżniające dany produkt lub dane produkty. Adres strony internetowej podaje się do wiadomości właściwego organu, który udzielił przymusowej licencji eksportowej.

Jeżeli produkt objęty przymusową licencja eksportową został opatentowany i jest chroniony także w krajach przywozu wymienionych we wniosku, wywóz produktu następuje wyłącznie, jeżeli kraje te udzieliły licencji przymusowej na przywóz, sprzedaż lub dystrybucję produktów. Organ właściwy w sprawie udzielenia przymusowej licencji eksportowej może, na wniosek posiadacza praw lub z urzędu, jeżeli prawo krajowe zezwala właściwemu organowi na działanie z urzędu, żądać udostępnienia ksiąg i rejestrów prowadzonych przez licencjobiorcę wyłącznie w celu sprawdzenia, czy warunki licencji, w szczególności warunki dotyczące miejsca przeznaczenia produktów, zostały spełnione. Księgi i rejestry powinny zawierać dowody wywozu produktów w postaci zgłoszeń wywozowych poświadczonych przez właściwe organy celne oraz dowody przywozu wydane przez właściwy podmiot.

Licencjobiorca jest odpowiedzialny za wypłatę posiadaczowi prawa wyłącznego (patentu) stosownego wynagrodzenia ustalonego przez organ właściwy w zakresie udzielenia przymusowej licencji eksportowej. Wynagrodzenie ustalane jest według następujących zasad: a) w sytuacjach krytycznych w kraju lub w innych nadzwyczajnych okolicznościach wymagających podjęcia pilnych działań, lub w wypadkach publicznego użycia dla celów niekomercyjnych, wynagrodzenie wynosi maksymalnie $4 \%$ łącznej ceny, która ma być uiszczona przez kraj przywozu lub w jego imieniu; b) we wszystkich pozostałych przypadkach wysokość wynagrodzenia ustala się przy uwzględnieniu wartości ekonomicznej korzystania dozwolonego zainteresowanemu krajowi lub krajom na podstawie licencji, jak również okoliczności humanitarnych i pozahandlowych związanych z udzieleniem licencji.

Warunki licencji nie odnoszą się do sposobów dystrybucji w kraju przywozu. Tym samym dystrybucja ta może być prowadzona na zasadach handlowych lub niehandlowych, w tym całkowicie nieodpłatnie.

Zgodnie $\mathrm{z}$ art. 16 rozporządzenia 816/2006 licencja przymusowa może zostać unieważniona decyzją organu właściwego do jej udzielenia, jeżeli licencjobiorca nie przestrzega warunków licencji. Organ ten jest upraw- 
niony do zbadania, na uzasadniony wniosek posiadacza praw lub licencjobiorcy, czy przestrzegane są warunki licencji. W odpowiednich przypadkach badanie to opiera się na ocenie dokonanej w kraju przywozu. O unieważnieniu licencji udzielonej na podstawie rozporządzenia 816/2006 zawiadamia się, za pośrednictwem Komisji, Radę ds. TRIPS. Po unieważnieniu licencji właściwy organ lub jakikolwiek inny organ wyznaczony przez państwo członkowskie jest uprawniony do wyznaczenia rozsądnego terminu, w którym licencjobiorca zadba o to, aby produkt będący w jego posiadaniu, pieczy, pod nadzorem lub kontrolą został przekazany na jego koszt do krajów będących w potrzebie, o których mowa $\mathrm{w}$ art. 4, lub został rozdysponowany w sposób ustalony przez właściwy organ lub przez inny organ wyznaczony przez państwo członkowskie, $\mathrm{w}$ porozumieniu z posiadaczem prawa.

Natomiast w przypadku, gdy kraj przywozu powiadomi organ właściwy w sprawie udzielenia przymusowej licencji eksportowej, że ilość określonego produktu farmaceutycznego stała się niewystarczająca do zaspokojenia jego potrzeb, organ ten może, na podstawie wniosku złożonego przez licencjobiorcę, zmienić warunki licencji, zezwalając na wytworzenie lub wywóz dodatkowych ilości produktu w ilości niezbędnej do zaspokojenia potrzeb danego kraju przywozu. W takich przypadkach wniosek licencjobiorcy rozpatrywany jest $\mathrm{w}$ ramach uproszczonej i przyspieszonej procedury, pod warunkiem że licencjobiorca wskaże pierwotnie udzieloną licencje przymusową.

Uznać należy, że licencja przymusowa stanowi publicznoprawne obciążenie patentu skuteczne wobec nabywcy. Tym samym każdy właściciel opatentowanego wynalazku, na który udzielono zezwolenia w drodze administracyjnej, jest obciążony publicznoprawnym obowiązkiem na rzecz licencjobiorcy przymusowego ${ }^{30}$. Ratio wprowadzenia tych ciężarów o charakterze publicznoprawnym to ochrona zdrowia i życia, zwłaszcza w tych obszarach świata, które ze względu na nierówności ekonomiczne (kraje słabo rozwinięte i rozwijające się) nie są w stanie skutecznie podjąć wyzwań w szczególności w walce z chorobami zakaźnymi. Organizacje międzynarodowe podkreślają jak ważne jest odpowiedzialne podejście

${ }^{30}$ Tak S. Sołtysiński, Licencje patentowe, [w:] J. Szwaja, A. Szajkowski (red.), System Prawa Własności Intelektualnej, t. 3, Prawo wynalazcze, Wrocław 1990, s. 504; S. Sołtysiński, [w:] R. Skubisz (red.), System Prawa Prywatnego, t. 14a, Prawo własności przemysłowej, Warszawa 2012, s. 654 i n.; a także P. Kostański, Komentarz. Prawo własności przemystowej, Warszawa 2014, s. $465 \mathrm{i} \mathrm{n.}$ 
do systemu licencjonowania przymusowego ${ }^{31}$, tak aby cele uzasadniające jego wprowadzenie mogły być osiągnięte. Cele dyktowane interesem publicznym nie mogą jednak prowadzić do deprecjacji praw właścicieli patentów. Równowaga powinna zostać zachowana. Wyzwaniem, jak się wydaje, jest także konieczność wskazania okresu obowiązywania licencji przymusowej. To się staje trudniejsze ze względu na fakt, że technologia szybko się zmienia, także ta podlegająca licencji przymusowej, i tym samym może zostać szybko wymieniona. Drugim wyzwaniem jest ustalenie prawidłowego poziomu opłat licencyjnych. Niezmiennie przeciwnicy tej instytucji przywołują argument osłabiania praw własności intelektualnej ${ }^{32}$. Podkreślić jednak należy, że to nie sam fakt wprowadzenia tej instytucji do porządku prawnego może osłabiać te prawa, ale raczej częstotliwość udzielania licencji przymusowych.

Dane statystyczne pokazują jednak niewielkie zainteresowanie tym instrumentem prawnym, uregulowanym w przyjętej deklaracji z Doha. Według badań opublikowanych w 2011 r. w latach 1996-2011 odnotowano 24 złożone wnioski o udzielnie licencji przymusowych, z czego połowa zakończyła się udzieleniem licencji przymusowych, w połowie przypadków zaś obniżono cenę lub zawarto umowę licencyjną - czyli poprzestano na rozwiązaniach, w których porozumienie $\mathrm{z}$ właścicielem patentu zostało zawarte. Szesnaście wniosków dotyczyło leków na HIV/AIDS, a cztery innych chorób zakaźnych, pozostałe cztery - leków na choroby nowotworowe. Ponad połowa wniosków dotyczyła średnio rozwiniętych krajów (włączając w to Brazylię i Tajlandię). Większość przypadków miała miejsce w latach 2003 i 2005, tuż po Konferencji, na której przyjęto deklarację z Doha, po roku 2006 zaobserwowano spadek zainteresowania tym narzędziem prawnym ${ }^{33}$.

Powstaje tym samym pytanie, czy zastosowano rozwiązanie prawne mało przydatne i nieadekwatne do stwierdzonych potrzeb? Opublikowane analizy i raporty pozwalają na postawienie tezy, że $\mathrm{w}$ istocie nie podjęto w oczekiwanych rozmiarach działalności, która w zamierzeniach

31 A. Miszczak, Licencjonowanie przymusowe..., s. 136.

32 Por. J. Tudor, Compulsory licensing..., s. 232.

${ }^{33}$ Relewantne dane statystyczne poddają wnikliwej analizie R. Beall, R.I. Kuhn, Trends in Compulsory Licensing of Pharmaceuticals Since the Doha Declaration: A Database Analysis, PLoS Med. 2012 Jan, https://www.ncbi.nlm.nih.gov/pmc/articles/PMC3254665/ [dostęp: 21.08.2017 r.]; omówienie konkretnych przypadków zawiera publikacja M.A. Desai, Compulsory licensing..., s. 38-43. 
twórców tego instrumentu miała stanowić istotny środek w ochronie zdrowia wykorzystywany $\mathrm{w}$ celu wyrównywania szans pomiędzy krajami, w szczególności w zapobieganiu i zwalczaniu chorób zakaźnych, a także przyspieszeniu rozwoju krajów adresatów korzyści wynikających z przymusowych licencji eksportowych. Nie pojawiły się podmioty zainteresowane uzyskaniem takich upoważnień, a tym samym same państwa zainteresowane $\mathrm{w}$ rzeczywistości nie przejawiały stosownej inicjatywy w tym przedmiocie. Przeszkodę stanowiły nie tylko trudności związane ze spełnieniem warunków do uzyskania licencji przymusowych, a dalej z ich dystrybucją - to wciąż istotny element hamujący rozwój tej instytucji. Poważnym czynnikiem tamującym był i jest nadal brak stosownych zabezpieczeń prawnych w zakresie praw własności intelektualnej w krajach docelowych. Chodzi tu przede wszystkim o takie rozwiązania prawne, które pozwalałyby na podjęcie skutecznych działań w odniesieniu do produktów leczniczych podrobionych lub sfałszowanych, które równolegle do leków objętych przymusową licencją eksportową pojawiały się na rynku ${ }^{34}$. Wydaje się, że sformułowany postulat odpowiedzialnego podejścia do systemu licencji przymusowych przez zainteresowane państwa nie został zrealizowany.

Dokonując analizy przyjętych rozwiązań prawnych dotyczących przymusowych licencji eksportowych, które starają się optymalizować proporcję wagi interesu publicznego i prywatnego w zakresie ochrony zdrowia w krajach słabo rozwiniętych, w tym zwalczania chorób zakaźnych, należy wskazać, że instrumenty te nie wydają się być efektywne. Pytanie, czy wynika to z wadliwie przyjętej konstrukcji prawnej, czy może raczej z uwarunkowań polityczno-ekonomicznych, które wydają się być tu istotniejszym czynnikiem determinującym skuteczność analizowanego instrumentu prawnego. Trudno jest udzielić jednoznacznej odpowiedzi, zwłaszcza że ocenie podlega instytucja o charakterze transgranicznym. W tym miejscu warto zauważyć, że osiągnięcie zrównoważonego dostępu do produktów leczniczych, także tych związanych z chorobami zakaźnymi, jest złożone i wymaga współpracy różnych elementów. Przede wszystkim dostęp wymaga silnego zaangażowania politycznego, systemu opieki zdrowotnej i odpowiedniej infrastruktury umożliwiającej transport pacjentów i sprzętu. Rutynowe stosowanie licencji przymusowych nie jest zgodne $\mathrm{z}$ inten-

${ }^{34}$ Por. M. Krawczyk, Compulsory Licensing of Pharmaceuticals since the Doha Declaration - a Public Health Triumph or Failure?, Zeszyty Naukowe Towarzystwa Doktorantów UJ Nauki Społeczne 2016, nr 15(4), s. 196 i podana tam literatura. 
cją z jaką przyjmowano stosowne zapisy TRIPS. Zapewnia jedynie rozwiązania krótkoterminowe, które mogą nie zaspokajać długoterminowej potrzeby, a zamiast zwiększać dostęp, może zniechęcić do wprowadzenia nowych leków. Chociaż w przypadku chorób zakaźnych, ze względu na ich transgraniczny charakter, instrument ten ma swoje specyficzne uzasadnienie. Historia wykazała, że przymusowe licencje są rzadko używane, ponieważ inne mechanizmy ułatwiające nabywanie leków w bardziej efektywny i zbalansowany sposób są skuteczną alternatywą.

W pewnych okolicznościach dobrowolne licencje często zapewniają coś więcej niż zwykłe licencje przymusowe i mogą obejmować w szczególności prawa do podstawowych technologii, know how i ekspertyzy technicznej. Innym mechanizmem o wykazanej skuteczności jest deklaracja braku własności intelektualnej (a non-assertion declaration). Jest to rozwiązanie, w którym zamiast aktywnego zaangażowania firmy innowacyjnej osiąga się porozumienie, że prawa własności intelektualnej nie będą uzyskiwane, pod warunkiem że spełnione są pewne kryteria, takie jak jakość produktu i rozmieszczenie geograficzne.

W krajach rozwijających się dodatkowo dostępność zwiększa się dzięki stosowaniu polityki cenowej skierowanej do wskazanego regionu czy kraju lub partnera z dodatkowymi obostrzeniami, np. zakazem wywozu czy stosowaniem licznych programów związanych $\mathrm{z}$ udzielaniem darowizny produktów.

Trudność powyższa nie zwalnia społeczności międzynarodowych z obowiązku poszukiwania efektywnych rozwiązań, w sytuacji gdy problem braku leków na HIV/AIDS lub inne chory zakaźne w krajach słabo rozwiniętych jest wciąż istotny ${ }^{35}$.

Słowa kluczowe: choroby zakaźne, szczepionki, patenty, licencja przymusowa, ochrona zdrowia.

\section{Bibliografia}

Abbott F.M., Puymbroeck R.V. Van, Compulsory Licensing for Public Health A Guide and Model Documents for Implementation of the Doha Declaration Paragraph 6 Decision, The World Bank Washington, 2005, http://documents.

${ }^{35}$ Według danych WHO w Afryce 1 na 25 dorosłych ludzi żyje z AIDS, co stanowi 2/3 całej populacji chorej na AIDS; http://www.who.int/gho/hiv/en/ [dostęp: 21.08.2017 r.]. 
worldbank.org/curated/en/173701468337882214/pdf/334260rev0pub.pdf [dostęp: 21.08.2017 r.].

Barczewski M., Prawa własności intelektualnej w Światowej Organizacji Handlu a dostęp do produktów leczniczych, Warszawa 2013.

Beaglehole R., Bonita R., Kjellström T., Podstawy epidemiologii, Szkoła Zdrowia Publicznego Instytutu Medycyny Pracy im. prof. J. Nofera, Łódź 2002.

Beall R., Kuhn R.I., Trends in Compulsory Licensing of Pharmaceuticals Since the Doha Declaration: A Database Analysis, PLoS Med. 2012 Jan; https://www. ncbi.nlm.nih.gov/pmc/articles/PMC3254665/ [dostęp: 21.08.2017 r.].

Desai M.A., Compulsory licensing: Procedural requirements under the TRIPS agreement, „Pharmaceuticals Policy and Law” 2016, vol. 18, s. 31-44.

Dobieżyński K., Licencja przymusowa w ustawie z 2000 r. Prawo własności przemysłowej (Charakterystyka ogólna), „Rzecznik Patentowy” 2010, nr 1, s. 44 i n.

Kampf R., Special Compulsory Licences For Export of Medicines: Key Features of WTO Members' Implementing Legislation, Staff Working Paper ERSD-20150731 July 2015; World Trade Organization Economic Research and Statistics Division; https://www.wto.org/english/res_e/reser_e/ersd201507_e. pdf [dostęp: 21.08.2017 r.].

Kerry VB, Lee K., TRIPS, The Doha declaration and paragraph 6 decision: what are the remaining steps for protecting access to medicines?, Global Health, 2007 May 24, https://www.ncbi.nlm.nih.gov/pmc/articles/PMC1892549/ [dostęp: 21.08.2017 r.].

Key Features of WTO Members' Implementing Legislation, Staff Working Paper ERSD-2015-07 31 July 2015, World Trade Organization Economic Research and Statistics Division; https://www.wto.org/english/res_e/reser_e/ ersd201507_e.pdf [dostęp: 21.08.2017 r.].

Kolasiński M.K., Ochrona własności intelektualnej w odniesieniu do farmaceutyków w państwach Trzeciego Świata, PiP 2007, nr 8.

Kolasiński M.K., Ograniczenia własności intelektualnej w analizie konstrukcyjnej, Zeszyty Naukowe Uniwersytetu Jagiellońskiego 2008.

Kostański P., Komentarz. Prawo własności przemystowej, Warszawa 2014.

Krawczyk M., Compulsory Licensing of Pharmaceuticals since the Doha Declaration - a Public Health Triumph or Failure?, Zeszyty Naukowe Towarzystwa Doktorantów UJ Nauki Społeczne 2016, nr 15(4).

Michalak A., Interes publiczny i jego oddziaływanie na powstanie, treść $i$ wykonywanie prawa własności intelektualnej, Warszawa 2012.

Miszczak A., Licencjonowanie przymusowe w prawie unijnym oraz umowach międzynarodowych wiażacych Rzeczpospolita Polska, RPEiS 2016, nr 4.

Patent Landscape Report on Vaccines for Selected Infectionues Diseases, przygotowany dla Światowej Organizacji Własności Intelektualnej przez France Innovation Scientifique \& Transfert FIST S.A., 2012, http://www.wipo.int/edocs/ pubdocs/en/patents/946/wipo_pub_946_3.pdf [dostęp: 21.08.2017 r.]. 
Promoting Access to Medical Technologies and Innovation. Intersections between public health, intellectual property and trade, World Health Organization, World Intellectual Property Organization and World Trade Organization 2013, https://www.wto.org/english/res_e/booksp_e/ pamtiwhowipowtoweb13_e.pdf [dostęp: 21.08.2017 r.].

Reichman J.H., Compulsory licensing of patented pharmaceutical inventions: evaluating the options, Law Med Ethics 2009 Summer, 37(2), s. 247-26; https:// www.ncbi.nlm.nih.gov/pmc/articles/PMC2893582 [dostęp: 21.08 .2017 r.].

Sołtysiński S., Licencja przymusowa, [w:] R. Skubisz (red.), System Prawa Prywatnego, t. 14a, Prawo własności przemystowej, Warszawa 2012.

Sołtysiński S., Licencje patentowe, [w:] J. Szwaja, A. Szajkowski (red.), System Prawa Własności Intelektualnej, t. 3, Prawo wynalazcze, Wrocław 1990.

Stankiewicz R., Model racjonalizacji dostępu do produktu leczniczego, Warszawa 2014.

Targosz T., Licencja przymusowa, [w:] E. Nowińska, K. Szczepanowska-Kozłowska (red.), System Prawa Handlowego, t. 3, Prawo własności przemystowej, Warszawa 2015.

Tudor J., Compulsory licensing in the European Union, "Journal of International Commercial Law", 2012, nr 2, s. 222 i n.

\section{EXPORT COMPULSORY LICENSE AS A PUBLIC INSTRUMENT FOR COMBATING AND PREVENTING INFECTIOUS DISEASES}

\section{S u m m a r y}

In the era of civilization progress and globalization, the problem of infectious diseases, prevention and combating it remains one of the important public health tasks. On the other hand, the specific nature and course of these illnesses is still an important profession for medicine, especially in the field of research and development, depending on the chemical and biological solutions, including drugs and vaccines, which will be effective. The public sector is condemned in this regard in most cases for the scientific and financial activity undertaken by the pharmaceutical industry. The latter, particularly when using the monopoly resulting from patent protection, is not always interested in directing its offer to underdeveloped markets. These areas are often sources of spreading epidemics. Hence the efforts of international organizations, followed by the European Union, to create legal instruments, such as compulsory export licenses, to counteract these unfavorable phenomena. It seems, however, that the introduction of a legislative formula is not sufficient to achieve the expected results without adequate political, economic and social support.

Key words: infectious diseases, vaccines, patents, compulsory licenses, health care. 


\title{
ПРИНУ ДИТЕЯЬНАЯ ЭКСПОРТНАЯ ЛИЦЕНЗИЯ КАК ПУБЯИЧНО- ЮРИДИЧЕСКИЙ ИНСТРУМЕНТ БОРЬБЫ И ПРЕДОТВРАЩЕНИЯ ИНФЕКЦИОННЫМ БОЛЕЗНЯМ
}

\author{
P е 3 ю м е
}

Во времени цивилизационного прогресса и связанной с ним глобализации проблема инфекционных болезней, их профилактики, как и борьба с последствиями является одним из существенных в публичных заданиях, которые содержаны в области здравоохранения. С другой же стороны специфика и ход этих болезней представдяет непрерывно существенный вызов для медицины, особенно в сфере, связанной с исследованиями и развитием, в связи с таких химических или биологических решений, учитывая лекарства и вакцинаций, которые будут эффективны. Публичный сектор приговорен к этому обстоятельству, в большинстве случаев, на научную и финансовую активность, которая осуществляется фармацевтической промышленностью. Последнее, особенно, когда пользуется монополией, которая возникает из полученной патентной охраной, однако, не всегда заинтересован управлением своего предложения к малоразвитым рынкам. Те же области, часто это источники эпидемий, которые распространяются. Следовательно, усилия международных организаций, а вслед за ними и Европейского Союза, чтобы создать юридические инструменты, такие как принудительная экспортная лицензия, которая позволяет противодействовать этим невыгодным явлениям. Однако кажется, что введение законодательной формулы недостаточно для достижения ожидаемых результатов, без соответственной политической, экономической и общественной поддержки.

Ключевые слова: инфекционные болезни, вакцины, патенты, принудительная лицензия, здравоохранение. 